\title{
Becoming an Activist: Ruth Harrison's Turn to Animal Welfare
}

Stephen and Clare's 1949 move from Ayot to Oxford coincided with their daughter Ruth's decision to abandon a potential artistic career in favour of paid employment. Her turn away from the arts in search of economic stability did not dampen Ruth's commitment to the reform values of her family or her already strong commitment to bearing witness to these values as an activist.

According to her mother's autobiography, Ruth's childhood had been a happy one. Living in immediate proximity to a Friends' (Quaker) Meeting House in Welwyn, Ruth was raised according to the 'natureoriented' tenets of the contemporary reform movement:

Our babes could be in the garden all day long, bare footed and most often bare. We had created a huge sand centre shielded by loganberry bushes and with pails and spade they were perpetually busy. On the lawn we built brick steps sapped with a stretch of grass so that they could climb and roll down on the other side. Soon we found the ideal roundabout cum see-saw and fixed it securely on the lawn. ${ }^{1}$

${ }^{1}$ Winsten Autobiography, 146; see also: 119 \& 153.

(C) The Author(s) 2021

C. Kirchhelle, Bearing Witness, Palgrave Studies in the History of Social Movements, https://doi.org/10.1007/978-3-030-62792-8_3 
Her parents' educational principles proved contentious among neighbours, who complained to the local police about the children's nudity and vegetarian diet, which was allegedly starving them. ${ }^{2}$ This did little to change Clare and Stephen's convictions. Ruth was subsequently enrolled in Welwyn's Montessori Community School, which her parents had cofounded, and attended the many cultural events organised by the Winstens - including lectures by Shaw. ${ }^{3}$

When the family moved back to Hampstead in London in the late 1920s, Ruth was placed in Parliament Hill School on the other side of Hampstead Heath, where she developed a strong interest in drama, artsand animals. ${ }^{4}$ According to her mother, this latter interest had been pronounced from early on and resulted in the repeated adoption of new animals by the household. During a vacation in Devon, Ruth:

helped the farm lady in the feeding of chickens, grooming the ponies, and otherwise helping the owner of this farm. At the end of our month's stay, we were seen off by the lady of the farm who handed a small cake box to Ruth. Thinking this a packet of sandwiches for our journey we thanked her and left. While in the train we heard a 'cheep cheep' coming from the box. To our amazement there were no sandwiches but a chicken! ${ }^{5}$

Ruth explained that the chicken had been neglected and kept in the barn for warmth where she had fed it all day: "This was an embarrassment because we lived in London. However to please little Ruth we took it home and it lived in the studio, and to keep it company Ruth persuaded us to buy a ginger kitten."

After finishing secondary school, Ruth pursued her interest in drama and enrolled as an English major in Bedford College, London University, in summer 1939. Because of the outbreak of war, her college was evacuated to Cambridge. ${ }^{7}$ Occurring parallel to her parents' move to Ayot, this move was highly significant in terms of Ruth's decision to join

${ }^{2}$ Winsten Autobiography, 132.

${ }^{3}$ Winsten Autobiography 119-120, 117, 161-162, 133.

${ }^{4}$ Ryder, "Harrison, Ruth (1920-2000)"; her mother recounts Ruth's shock at seeing a cat killing a rabbit in Sussex, Winsten Autobiography, 134A.

${ }^{5}$ Winsten Autobiography, 139-140/ 166-167.

${ }^{6}$ Winsten Autobiography, 139-140/ 166-167.

${ }^{7}$ Ryder, "Harrison, Ruth (1920-2000)". 
the local theist Society of Friends (Quakers) ${ }^{8}$ As the daughter of a vegetarian New Woman and a conscientious objector, many core tenets of British Quakerism's “middle-class radicalism” would have been familiar to her. Founded in the northwest of England in 1652, Quakerism holds that there is something of God in everyone. Because of this belief, Quakers place a strong emphasis on social justice, equality, and pacifism. Another important part of Quakerism consists of living faith through peaceful action and registering disapproval against grievances. ${ }^{10}$ Also known as bearing witness, this practice of peaceful protest made Quakers play highly visible roles in nineteenth- and twentieth-century anti-slavery, temperance, and social justice movements. Some Quakers also extended the principle of the sanctity of life and non-violence to animals and supported the antivivisection movement. Founded in 1902, the Friends' Vegetarian Society in particular dedicated itself to bearing witness against cruelty to animals and spreading vegetarianism and other reform principles among fellow Quakers. ${ }^{11}$ It is not difficult to see why this fusion of compassion for humans and animals, non-violent mode of bearing witness to injustice, and tradition of middle-class radicalism made Quakerism appeal to Ruth.

The fact that her conversion occurred in Cambridge was doubly significant because it brought Ruth into the vicinity of a leading British expert in animal behaviour. Prior to becoming a fully 'convinced' (converted) Friend, Ruth would have regularly attended meetings of Cambridge's local Society of Friends. ${ }^{12}$ While doing so, she likely met William Homan Thorpe. Thorpe was an influential Cambridge entomologist and animal behaviourist. During the early 1940s, he was not only committing to Quakerism himself but also developing a synthesist fusion of Darwinian evolution and Christianity centring on animal cognition (see Chap. 4). This research would provide important scientific support for Ruth's

\footnotetext{
${ }^{8}$ Kendall, "Ruth and the Ruthless," 2; Van De Weerd and Sandilands, "Bringing the Issue of Animal Welfare to the Public," 404.

${ }^{9}$ Frank Parkin, Middle Class Radicalism: The Social Bases of the British Campaign for Nuclear Disarmament (Manchester: Manchester University Press, 1968), 2-5.

${ }^{10}$ Pink Dandelion, The Quakers: A Very Short Introduction (Oxford: Oxford University Press, 2008), 1-2, 36.

${ }^{11}$ Dandelion, The Quakers, 33-35; Julia Twigg, The Vegetarian Movement in England, 1847-1981: A Study In The Structure Of Its Ideology (London: Dissertation London School of Economics, 1981), Chapter 7.IV.

12 "Chapter 11: Membership", Quaker Faith and Practice 5th edition, https://qfp.quaker. org.uk/chapter/11/ [08.11.2019].
} 
campaigning in the 1960s. However, in the short term, Thorpe likely also facilitated Ruth's first activist experience in his role as chairman of Cambridge's Pacifists' Service Bureau, which helped local Quakers and other conscientious objectors find wartime work in organisations like the Friends' Ambulance Unit (FAU). ${ }^{13}$

Founded in accordance with the Quaker peace testimony, the FAU had provided medical relief for combatants and civilians of all nationalities during the First World War. In September 1939, the FAU was refounded by former members. Early FAU work was far from glamorous. Despite being eager to help, most FAU volunteers had limited medical experience and found themselves changing linen, cleaning wards, and performing basic nursing duties. Starting in September 1940, the Blitz changed this situation. Headquartered in London's Whitechapel neighbourhood, the FAU provided important emergency aid and rapidly expanded its activities, first throughout Britain and then abroad. In total, the FAU trained 1300 volunteers as ambulance drivers, medical orderlies, and unqualified nurses. Women were allowed to aid FAU relief work from October 1940 onwards. By 1941, they were permitted to train as full FAU members. Overall, 97 women would train with and work for the FAU. ${ }^{14}$

Ruth was one of these 97 women. Aged 23, she joined the FAU in 1943 and attended a 14-day FAU training course before starting work as an unqualified nurse in Hackney Hospital. ${ }^{15}$ According to a later interview, her first day of work left a marked impression on her:

after seeing festering ulcers, [I] went home and sobbed all night. 'At dawn I said, 'Come on, girl, get some guts,' so I went back and made myself work all day on the worst ulcers, the nastiest whitlows. It was a slog, but searing. ${ }^{16}$

${ }^{13}$ R.A. Hinde, "William Homan Thorpe. I April 1902-7 April 1986," Biographical Memoirs of Fellows of the Royal Society 33 (1987), 625; Oral History Interview Donald Broom (04.07.2014).

${ }^{14}$ A. Tegla Davies, Friends Ambulance Unit. The Story of the F.A.U. in the Second World War 1939-1945 (London: George Allen and Unwin Limited, 1947); "Quakers in Action. Women in the FAU", Quakers in the World, http://www.quakersintheworld.org/quakersin-action/329 [08.06.2016].

${ }^{15}$ Library of the Society of Friends [in the following LSF], Friends' Ambulance Unit [in the following FAU] Record Cards, Ruth Winsten, 1.

16 "Debt of honour", Observer, 02.09.1973, 40; while the Observer claims that Harrison was unqualified, Harrison's son, Jonathan, notes that she passed her nursing exam with a score of 99 per cent (Correspondence with Jonathan Harrison 29.08.2015); Richard Overy, "Pacifism and the Blitz, 1940-1941," Past \& Present 219 (2013), 217-18. 
Although the most intensive phase of the Blitz had already passed, work within metropolitan hospitals was not without its dangers. British cities were still subjected to occasional bombing, and nurses like Ruth could fall victim to hospital-acquired infections. After four months of work at Hackney Hospital and in Lichfield, Ruth contracted scarlet fever and was placed in Burton Isolation Hospital before being sent to convalesce with her parents in Ayot. She returned to work within two months and spent the period between 1944 and mid-1945 working at St Mary's Islington Hospital, Hackney Hospital, Queen Elizabeth Hospital, and in FAU administrative hubs in London (Images 3.1 and 3.2). ${ }^{17}$

With pressure on British hospitals declining after D-day in 1944, many FAU volunteers began to look for alternative postings. Postings abroad

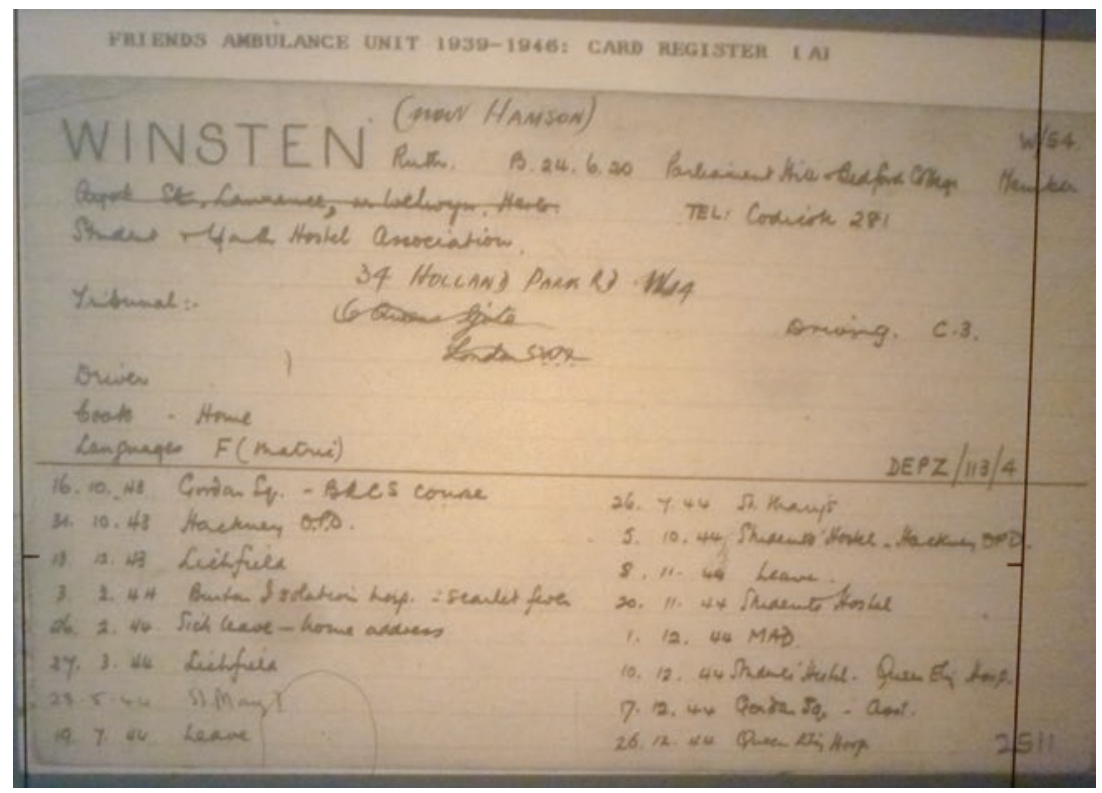

Image 3.1 Picture in Friends' Ambulance Unit Card Register (courtesy of Friends' Library, London)

${ }^{17}$ LSF, FAU Record Cards, Ruth Winsten, 1. 


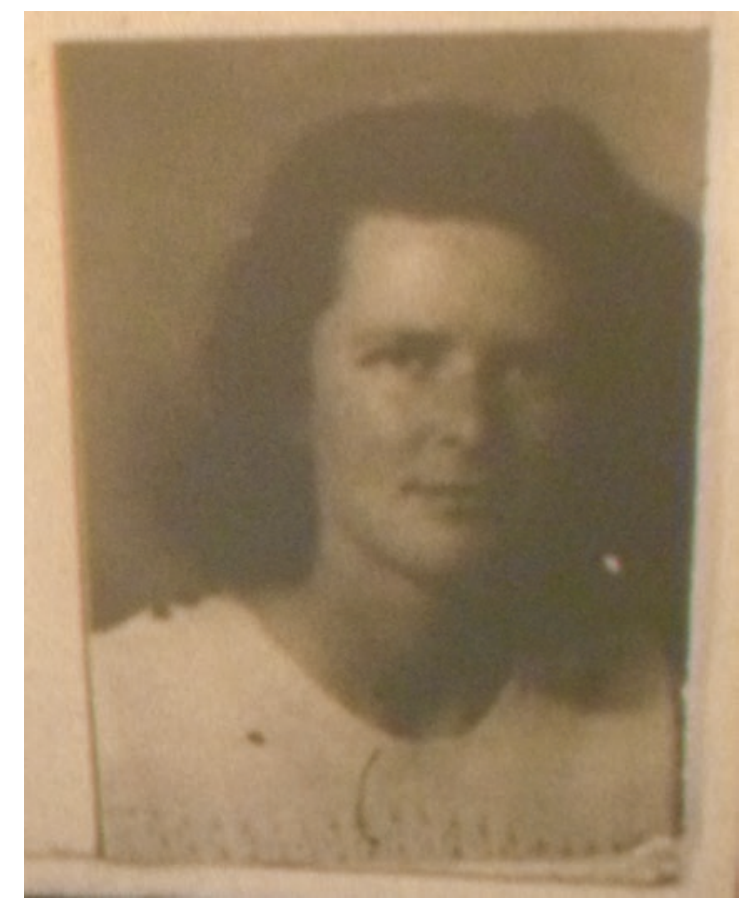

Image 3.2 Ruth Winsten Personnel File (courtesy of Friends' Library, London)

were particularly prestigious. Since the early 1940s, FAU ambulance sections had been active in Finland, Norway, Greece, China, Syria, India, and then in Italy, France, and Germany. Many of these sections were mixed gender. However, due to their integration with military units, FAU sections in Northern Europe were initially all-male. This was difficult to stomach for the daughter of a New Woman. Writing to the FAU's Executive Committee in January 1945, Ruth drew attention to female FAU members' desire to aid European relief efforts. After a meeting with female members, the executive committee agreed to change course. By June 1945, the first female FAU workers joined male colleagues in continental Displaced Persons camps. ${ }^{18}$

${ }^{18}$ LSF, FAU Executive Committee Minutes Feb. 1945 to Dec. 1945, Minutes of Meeting of the Executive Council, 01.02.1945, item 3153, 1; "Quakers in Action. Women in the FAU", Quakers in the World; "Quakers in Action. FAU in WWII: Civilian Relief Work in 
As the daughter of ethnic Jews, Ruth made the remarkable decision to aid FAU relief efforts in occupied Germany. ${ }^{19}$ Having attended a German language course in June 1945, she was supposed to join one of the first mixed FAU units in early July. However, sickness delayed her departure. ${ }^{20}$ By the time of her arrival in August 1945, there were 150 FAU members working in Germany. ${ }^{21}$ As one of only 57 female FAU members to work abroad, Ruth was assigned to FAU Section 133. Between 1945 and 1946, she was deployed in Bochum in the Ruhr area and in the small town of Husum close to Schleswig-Holstein's Danish border, which had been the site of a concentration camp outpost for foreign labourers. ${ }^{22}$

Regular reports from FAU Sections give insight into Ruth's work. Initially, FAU Section 133 provided relief and repatriation services for former concentration and labour camp inmates and non-Germans. Following the relaxation of fraternisation restrictions in mid 1945, the FAU also helped to establish refugee camps and provide education, food, and medical relief for German civilians. ${ }^{23}$ Conditions were difficult. In their reports, FAU members expressed concern about the humanitarian situation in bombed-out cities. With only limited access to food, sanitation, and medical services, diseases spread quickly and mortality was high. Liaising with local volunteers, FAU workers were also keenly aware that many of their German counterparts had until recently formed part of the Nazi machinery. However, in accordance with its Quaker convictions, the FAU hoped that reconstruction and relief would create a new peaceful Germany. As a consequence, it played an important role in raising awareness about the appalling living conditions of German children and other vulnerable people amongst local Allied military authorities and in Britain. Setting out its education programme for Duisburg youths and unaccompanied children living in bunkers in December 1945, FAU Section 5 warned that rhetorical commitments to a new Germany were not enough in a situation "where living is so often a matter of cold, (...) and hungry bellies." ${ }^{24}$ Ruth's FAU section

Mainland Europe", Quakers in the World (http://www.quakersintheworld.org/quakers-inaction/295 [08.06.2016]).

${ }^{19}$ Ryder, "Harrison, Ruth (1920-2000)"; Van De Weerd and Sandilands, "Bringing the Issue of Animal Welfare to the Public," 404.

${ }^{20}$ LSF, FAU Record Cards, Ruth Winsten, 2.

21 "Quakers in Action. Women in the FAU," Quakers in the World.

22 "Quakers in Action"; Ryder, "Harrison, Ruth (1920-2000)"; Davies, Friends Ambulance Unit, 435 .

23 "Quakers in Action: FAU in WWII: Civilian Relief Work in Mainland Europe," Quakers in the World.

${ }^{24}$ LSF, FAU Records, Folder "German Relief", "Young People from 0-18 Years in Duisburg, Germany", 2. 
pressured British authorities to provide fuel for hospitals and nurseries, monitored the situation of displaced children and German refugees in Denmark, and reported on dramatic hikes of infant mortality. ${ }^{25}$ The FAU also assessed the ideological state of German youth organisations, re-established contact with German Friends, and monitored evangelical churches. ${ }^{26}$

Despite its success as a relief organisation, the FAU had not been designed for prolonged post-war activity. About a year after Nazi Germany's defeat, it began to wind down its international work. While a small number of personnel continued to provide relief on the continent, the majority of FAU members were withdrawn and resigned from active duty by summer $1946 .{ }^{27}$ After nearly three years of FAU work and ten months in Germany, Ruth returned to Britain in mid-June 1946 and resigned from the FAU in mid-July. ${ }^{28}$ The war undoubtedly marked a turning point in her life. In addition to converting to Quakerism, her decision to join the FAU and volunteer in Germany-despite her Jewish family background-highlights how far she would go to bear witness to humanitarian causes in which she believed.

Back in Britain, the now 26-year-old Ruth continued her university studies and enrolled at the prestigious Royal Academy of Dramatic Art (RADA). Her sister, Theodora, also a RADA graduate, studied stage design down the road at their mother's old school, the Slade. Ruth showed talent. Before she joined RADA, George Bernard Shaw coached her to throw her voice in the church at Ayot St Lawrence. ${ }^{29}$ At RADA, Ruth conducted her own production of J.B. Priestley's An Inspector Calls. ${ }^{30}$ Priestley himself complimented Ruth on the production. In the same year, Harrison also won RADA's oneact-play competition. ${ }^{31}$ Recognising her promise, Shaw unsuccessfully recommended Ruth as producer for the 1949 Malvern Festival production of his In Good King Charles's Golden Days (Image 3.3):

${ }^{25}$ LSF, FAU Records, Folder “German Relief”, FAU Relief Section 133, Harold Cadows, "Report on fuel supply in Bochum" (19.02.1946); Beatrice Thrift, "Refugee Camps in Denmark" (01.03.1946); Pip Turner, "Population Statistics for Bochum for the year of 1945"; Idem., "Statistics of Infectious Diseases in Bochum January-February 1946" (28.03.1946); Idem, "Population Statistics for Bochum for the month of March 1946" (04.05.1946); "Report on the administration of education in Gelsenkirchen" (29.12.1945).

${ }^{26}$ LSF, FAU Records, Folder "German Relief", The Evangelical Church in Bochum (report); Observations on German Political Movements (report).

${ }^{27}$ Davies, Friends Ambulance Unit, 439-440.

${ }^{28}$ LSF, FAU Record Cards, Ruth Winsten, 2.

${ }^{29}$ Correspondence with Jonathan Harrison (29.08.2015)

${ }^{30}$ Van De Weerd and Sandilands, "Bringing the Issue of Animal Welfare to the Public," 404.

${ }^{31}$ Ryder, "Harrison, Ruth (1920-2000)"; Correspondence with Jonathan Harrison (21.01.2015); Dan. H. Laurence, Theatrics, 231. 


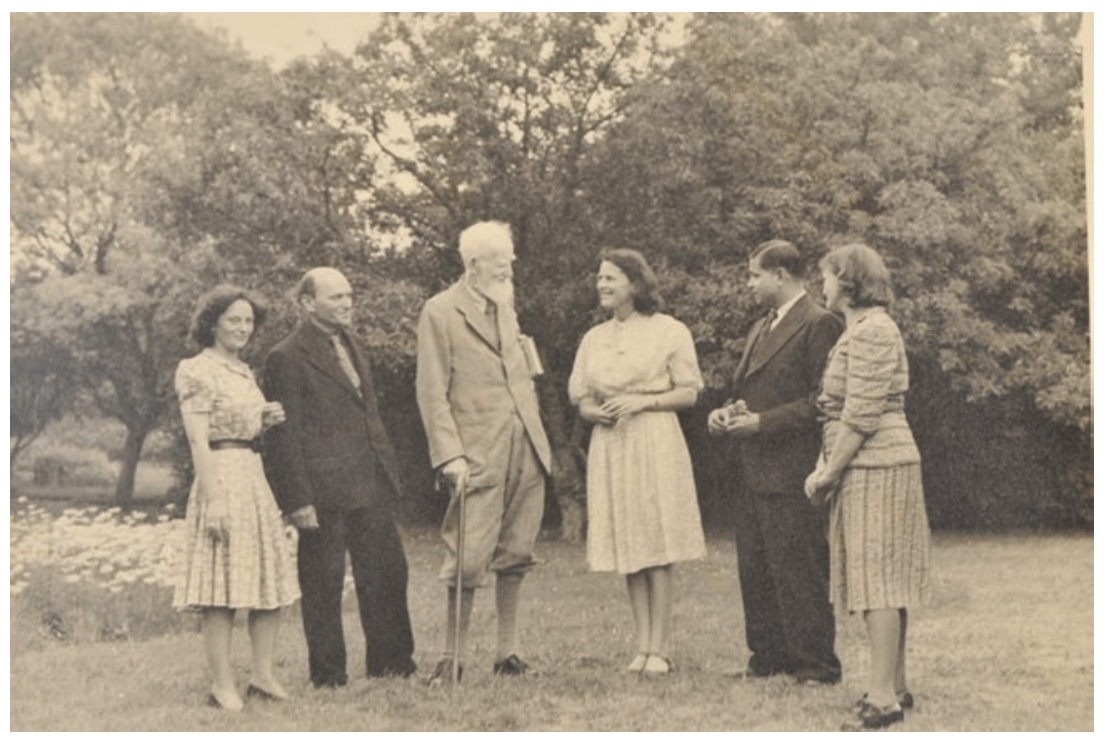

Image 3.3 Theodora and Stephen Winsten, George Bernard Shaw, Ruth Winsten, Devdas Gandhi (son of Mohandas Gandhi) and Clare Winsten at Ayot St. Lawrence (ca. 1949) (image courtesy of Jonathan Harrison)

She is in every way a desirable person in the theatre, and understands that my plays are essentially religious and serious, however entertaining they may be, and no matter how many laughs they may get when the actors don't play for them. I could trust her to produce much more hopefully than these 'Where's your murder?' chaps. ${ }^{32}$

Despite these glowing endorsements, Ruth decided not to pursue a career in the dramatic arts. ${ }^{33}$ Coinciding with her parents' departure from Ayot, she joined the architectural firm Harrison and Seel. In 1954, she married the company's senior partner Dexter 'Dex' Harrison (1909-1987). ${ }^{34}$ Dex had studied at Leeds School of Architecture and moved to London in the 1930s. During the war, he had worked for the Ministry of Works and authored a major Survey of Prefabrication (1945) in preparation for British post-war reconstruction. After 1945, he was

${ }^{32}$ Quoted according to Laurence, Theatrics, 230.

${ }^{33}$ Ena Kendall, "Ruth and the Ruthless," 2.

34 "Dex Harrison-Basic Biographical Details", Dictionary of Scottish Architects, Architect Biography Report http://www.scottisharchitects.org.uk/architect_full.php?id=206027 [20.12.2014]. 
chief architect of the 1951 Festival of Britain's pleasure gardens and designed the new theatre and other buildings around Battersea Park. ${ }^{35}$ Although Dex remained a meat-eater, his 1954 marriage to Ruth was happy. In 1955 and 1956, the couple had two children, while Ruth complied with contemporary mores and became a housewife in a "calm studio house in [London Kensington] with ... two pianos but only one cat" 36 (Image 3.4).

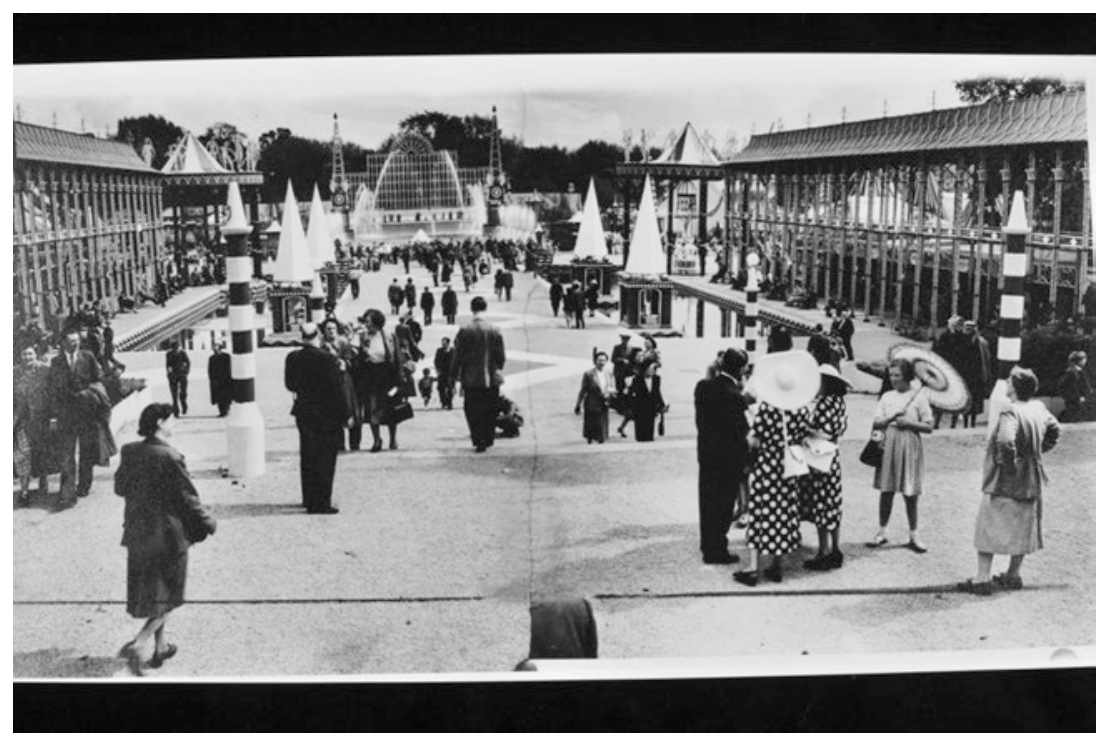

Image 3.4 Dex Harrison's pleasure gardens at the 1951 Festival of Britain (image courtesy of Jonathan Harrison)

35 "Dex Harrison-Basic Biographical Details"; "Obituary-Dex Harrison," The Times (15.01.1988), 14.

36 "Debt of honour", Observer, 02.09.1973, 40; for studies on the effect of marriage and motherhood on women's careers during the 1950s and 1960s, see Sarah Aiston, "A Good Job for a Girl? The Career Biographies of Women Graduates of the University of Liverpool Post-1945," Twentieth Century British History, 15/4 (2004), Carol Dyhouse, "Family Patterns of Social Mobility through Higher Education in England in the 1930s, Journal of Social History, 34/4 (2001), Dolly Smith Wilson, "A New Look at the Affluent Worker: The Good Working Mother in Post-War Britain," Twentieth Century British History, 17 /2 (2006). 
Life did not stay quiet for long. Like many Quakers, Harrison supported the Campaign for Nuclear Disarmament (CND). Officially founded in February 1958, the CND united many different groups with its call for unilateral nuclear disarmament. Its foundation was triggered by concerns about nuclear testing and a new generation of hydrogen bombs, whose destructive power far exceeded previous nuclear weapons. Supported by a broad alliance of Labour activists, church leaders, and the Peace Pledge Union, the CND became the largest British extra parliamentary organisation after 1945. In 1961, its annual Aldermaston march attracted ca. 150,000 people. The movement also germinated new forms of protest. Founded in 1960, the Committee of 100 was led by the charismatic philosopher Bertrand Russell, an acquaintance of Harrison's maternal uncle Jonas Birnberg, and coordinated civil disobedience in the form of nonviolent direct action like sit-ins. ${ }^{37}$

Although CND demands for unilateral disarmament were ultimately ignored, the peace movement provided important impulses for post-war environmentalism. In Britain, many CND-campaigners soon expanded their protest to encompass destructive non-nuclear technologies and the global threat posed by environmental degradation. In doing so, these campaigners contributed to what some historians describe as the 1960s' shift from an anthropocentric to an ecocentric view of the world. Early British environmentalist and CND activists likewise often shared a yearning for an allegedly simpler past and a distrust of post-war technologies. ${ }^{38}$

Quakers played a prominent role in both the transatlantic peace and environmentalist movements. In a 1965 survey of 368 British CND members, a remarkable 10 per cent of respondents described themselves as Quaker (14 per cent were Church of England, 15 per cent atheist, 15 per cent humanist, and 19 per cent agnostic) ${ }^{39}$ even though there were only 15,000-20,000 registered Quakers in Britain. ${ }^{40}$ Focusing on the US, historian Frank Zelko has highlighted the importance of Quaker convictions for early Greenpeace activists like Irving and Dorothy Stowe. In an interesting

${ }^{37}$ Oral History Interview Donald Broom (04.07.2014); on Christians and the CND see Adam Lent, British Social Movements since 1945, 41-45, Veldman, Fantasy, 115-200; Burkett, "The Campaign for Nuclear Disarmament," 627-632; Harrison's parents might have participated in the anti-war rallies on Trafalgar Square in 1914; Macdougall, "Whitechapel Girl," 112.

${ }^{38}$ Veldman, Fantasy, 115-180; Burkett, "The Campaign for Nuclear Disarmament," 626-627.

${ }^{39}$ Parkin, Middle Class Radicalism, 27.

${ }^{40}$ James Chadkirka, Patterns of Membership and Participation among British Quakers, 1823-2012 (MA thesis, University of Birmingham, 2014), 58. 
parallel to Ruth Harrison, the Stowes grew up as liberal Jews on the US East Coast during the interwar period but were drawn to Quaker humanism during the late 1940s. Following the US' use of nuclear weapons against Japan, the Stowes participated in anti-nuclear peace movement campaigns and went on to form the core of Greenpeace in the 1960s. According to Zelko, the concept of bearing witness - that is, "registering one's disapproval of an activity and putting moral pressure on the perpetrators"41 — made the Stowes and other Quakers inherently attracted to post-war Civil Rights, antinuclear, and environmental movements. ${ }^{42}$ To this day, environmentalist values and eco-spiritualism form an important part of global Quaker thinking about non-ostentatious plainness, sustainability, and social justice. ${ }^{43}$

In the British context, Quakers' commitment to environmentalist values and peacefully bearing witness to humanitarian values is key to understanding Ruth Harrison's decision to write Animal Machines. When the Crusade Against All Cruelty to Animals pushed a leaflet against 'factory farming' through her door around $1960,{ }^{44}$ they spurred to action a politically compatible and well-connected Quaker, who knew the power of civic activism. The leaflet itself contained a series of disturbing images and descriptions of animals' living conditions under intensive housing and slaughtering practices in abattoirs. Calling for more legislative protection, it exhorted readers to join the Crusade and write to their MPs and newspapers in protest. ${ }^{45}$ According to a 1990 interview, Ruth Harrison's initial reaction was to do nothing. As a "life-long vegetarian," she felt that a campaign for farm animals did not concern her: "But "in doing nothing I was allowing it to happen'"46 (Image 3.5).

${ }^{41}$ Zelko, Make It a Green Peace!, 13.

${ }^{42}$ Zelko, Make It a Green Peace!, 11-15; 20-27; 32.

${ }^{43}$ Peter Jeffrey Collins, "The development of ecospirituality among British Quakers," Ecozon@ 2/2 (2011); Timothy Burdick and Pink Dandelion, "Global Quakerism 1920-2015," in Stephen W. Angell and Pink Dandelion (eds.), The Cambridge Companion to Quakerism (Cambridge: Cambridge University Press, 2018), 49-66; Emma Jones Lapsansky, "The Changing World of Quaker Material Culture," in Stephen W. Angell and Pink Dandelion (eds.), The Cambridge Companion to Quakerism (Cambridge: Cambridge University Press, 2018), 147-158.

${ }^{44}$ There are conflicting dates regarding the leaflet; whereas Helen van de Weerd and Victoria Sandilands claim that Harrison received the leaflet in 1961, Ena Kendall holds that Harrison received in the late 1950s; in 1990, the Guardian reported that Harrison received the leaflet in 1960; Van De Weerd and Sandilands, "Bringing the Issue of Animal Welfare to the Public," 405; Kendall, "Ruth and the Ruthless," 2; Colin Spencer and Spike Gerrel, "A rare breed at the factory farm", Guardian, 03.11.1990, A19.

${ }^{45}$ Van De Weerd and Sandilands, "Bringing the Issue of Animal Welfare to the Public," 407.

${ }^{46}$ Quoted according to Colin Spencer and Spike Gerrel, "A rare breed at the factory farm", Guardian, 03.11.1990, A19. 


\section{WHAT YOU CAN DO}

28

Refuse to buy forced white veal and broiler chickens and tell the shopkeeper why. Cut-price chickens can only be obtained by broiler methods.

S? Do all you can to avoid buying battery eggs. Ask for FREE RANGE eggs or buy DANISH. Tell the shopkeeper you prefer British eggs but will not buy while they are produced by battery methods.

13 Write to your Member of Parliament, House of Commons, London, S.W.1. protesting against the broiler and battery systems and ask him to take action on the matter. There are attempts to give the Minister of Agriculture, Fisheries and Food and the Secretary of State for Scotland power to make regulations concerning intensive methods of food production, i.e. the broile calf and chicken industries, but this would allow the system to
continue even if in modified form.

We want an amendment to the PROTECTION OF ANIMALS ACT, 1911, to make these systems illegal. We appeal to you is the name of sanity to write to your M.P. asking him to support us in this.

23 Ask your M.P. to agitate at once for all "broiler" chickens. forced white veal and battery eggs to be marked as such so that you, the public, can make the choice you are entitled as frec individua

5 Write to the national and local papers about it and keep writing. Talk about it in your local societies and church organisations and when you go shopping.

S. Join our national campaign against these evils as announced in THE DAILY MIRROR of December 8, 1960. ITemember.." .II that is necessary for the triumph
of evil is that geed men do nething". Issued by CRISADE AgaIIST ALL CRIELTY TO ANIMALS

3, Woodfield Way, Bounds Green Rd., London, N.11. CAPTIVE ANIINAS' PROTECTION SOCIETY Further copies of this leastet can be obeained from the above addres free of chane bot

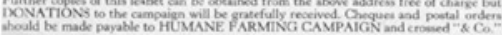

\section{Cheap food? YES!} BUT IS IT GOOD FOOD?

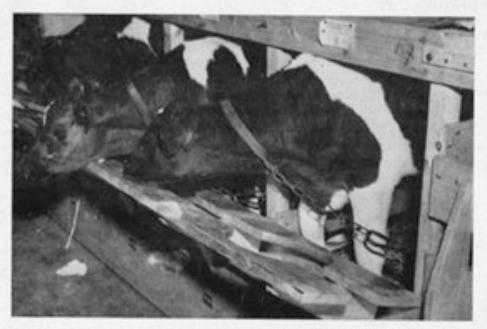

"BROILER" CALVES - in prison for life ?

The Dutch method of rearing calves for veal has recently been introduced iato this country and is being developed despite public protest What it is

Calves are reared in unnatural conditions, their movements deliberately restricted either in small pens or separate stalls and sometimes by tethering, in many cases deprived of light except at feeding times and even then given only artificial light, and fed on an unnatural diet including drugs. These methods are used to force quick growth and white meat. After lives of complete imprisonment the calves are slaughtered at the age of 12 weeks to give YOU CHEAP VEAL

\section{A srowing evil}

Similar intensified unnatural methods are now being extended to other animals. It is easy to see that unless public opinion calls a halt to this false progress NOW the day is very near when all our farm animals wil be kept in factories tier upon tier.

We have proof of this in the frightening growth of the broiler chicken industry in this country. In 1960 the British public in their ignorance bought one hundred million broiler chickens. The industry confidently anticipates that the same public will purchase one hundred and thirty.
five million chickens in 1961 .

Image 3.5 Leaflet by the Crusade Against All Cruelty To Animals pushed through Harrison's letterbox around 1960 (image courtesy of Marlene Halverson)

Harrison's use of language, which strongly resembles the Quaker principle of living faith through action, is just as telling as her initial decision to campaign for animal welfare within the Quaker movement. However, despite forwarding the leaflet "to every Friends Meeting in the country,"47 reactions were discouraging. Of a total of 20 replies, 18 said "there was enough suffering among humans without getting involved in animals."48 For Ruth Harrison, this was not enough. Following the suggestion of a friend and supported by her husband, ${ }^{49}$ she decided to write a comprehensive account to bear witness against intensive animal husbandry. ${ }^{50}$

${ }^{47}$ Spencer and Gerrel, "A rare breed at the factory farm".

${ }^{48}$ Spencer and Gerrel, "A rare breed at the factory farm".

${ }^{49}$ Spencer and Gerrel, "A rare breed at the factory farm".

${ }^{50}$ According to a later interview, Dex Harrison "backed [Ruth Harrison] to the hilt, although in the early days he was fairly detached about her work. Then one day he drove her to a research unit she wanted to look at. (...). The emotional impact on [Dex Harrison] was quite big." Kendall, "Ruth the Ruthless," 2; Dex Harrison also took many of the pictures, which appeared in Animal Machines. 
Sixty years after the Crusade's leaflet landed in her letterbox, Harrison's decision to write Animal Machines remains remarkable. However, in contrast to heroic tales of her spontaneous emergence as a bestselling author, ${ }^{51}$ surveying the years before 1960 reveals deep roots connecting Animal Machines and its author to the radical world of Edwardian reform. Her family background, Quakerism, training in the dramatic arts, and experiences within the FAU and CND made Harrison a perfect rebel waiting for a cause. Knowing this context is important. Harrison's experiences not only predisposed her to take up the topic of animal welfare but also made her target specific issues more than others. As dystopian sites of alleged animal suffering, environmental hazards, and moral degradation, 'factory farms' presented an ideal target for an activist concerned about modern technology's threat to peace, society, and the environment. This was true not only for Harrison but also for many of the other scientists, campaigners, and politicians gravitating towards animal welfare after 1945. As Part II shows, their rootedness in a similar cultural milieu and desire for a moral reordering of society facilitated personal friendships and would shape the trajectory of British farm animal welfare for decades to come.

${ }^{51}$ Webster, "Ruth Harrison," 6; Roscher, Königreich, 260; Ryder, Animal Revolution, 165.

Open Access This chapter is licensed under the terms of the Creative Commons Attribution 4.0 International License (http://creativecommons.org/licenses/ by $/ 4.0 /$ ), which permits use, sharing, adaptation, distribution and reproduction in any medium or format, as long as you give appropriate credit to the original author(s) and the source, provide a link to the Creative Commons licence and indicate if changes were made.

The images or other third party material in this chapter are included in the chapter's Creative Commons licence, unless indicated otherwise in a credit line to the material. If material is not included in the chapter's Creative Commons licence and your intended use is not permitted by statutory regulation or exceeds the permitted use, you will need to obtain permission directly from the copyright holder.

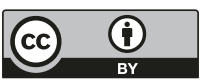

